\title{
Juvenile systemic lupus erythematosus: a retrospective study in a single center over a 13 years period
}

\author{
N Conejo, O Porras ${ }^{*}$ \\ From 18th Pediatric Rheumatology European Society (PReS) Congress \\ Bruges, Belgium. 14-18 September 2011
}

\begin{abstract}
Aim
To evaluate a group of children diagnosed as juvenile systemic lupus erythematosus (JSLE) in a single center over a 13-year period.

\section{Methods}

JSLE patients, age $\leq 18$ years, were included. Clinical presentation, laboratory parameters and therapeutic approaches were analyzed at diagnosis. Outcome, response and adverse events to treatment were analyzed during the follow up period.
\end{abstract}

\section{Results}

74 cases were included, $78.3 \%$ females. The mean age at diagnosis was 9.9 years, $54 \%$ were children of age 6-10 years and $35.1 \%$ were of age $11-14$ years. The most frequent pre-diagnosis manifestations were fever, arthralgias, asthenia, adinamia, weight loss, headaches and anorexia. The four most frequent classification criteria were a positive ANA (91.7\%), positive immunoserology (95.9\%), cytopenia $(75.7 \%)$ and nephritis $(58.1 \%)$. The main complications were associated to nephritis (58.1\%), central nervous system (40.5\%) and infection (24.3\%). Seventy cases had flares, in relation with nephritis (35.7\%), malar rash $(27,1 \%)$, arthritis $(20 \%)$, vasculitis $(15.7 \%)$, serositis $(11.4 \%)$ and cytopenias $(10 \%)$. Fifteen children died (20.3\%), due to septic shock, chronic renal insufficiency, autoimmune hepatitis, cerebral infarct, lung hemorrhage, hypertensive encephalitis, antiphospholipid syndrome and renal thrombosis. Death occurs a mean of 2.5 years ( 9 days to 7.9 years) after diagnosis.

* Correspondence: porrasza@racsa.co.cr

National Children's Hospital "Dr. Carlos Sáenz Herrera", Department of

Pediatric Immunology and Rheumatology, San José, Costa Rica

\section{Conclusions}

A group of 74 children with JSLE were evaluated, most of them female. Half of the cases developed nephritis. A fifth of the cases died during the study period, mainly from infection. The analysis of the studied group allows us to obtain clinical information crucial to define diagnosis and treatment guidelines and develop medical education material.

Published: 14 September 2011

doi:10.1186/1546-0096-9-S1-P266

Cite this article as: Conejo and Porras: Juvenile systemic lupus

erythematosus: a retrospective study in a single center over a 13 years period. Pediatric Rheumatology 2011 9(Suppl 1):P266.

Submit your next manuscript to BioMed Central and take full advantage of:

- Convenient online submission

- Thorough peer review

- No space constraints or color figure charges

- Immediate publication on acceptance

- Inclusion in PubMed, CAS, Scopus and Google Scholar

- Research which is freely available for redistribution

Submit your manuscript at www.biomedcentral.com/submit
() Biomed Central
C Biomed Central

(c) 2011 Conejo and Porras; licensee BioMed Central Ltd. This is an open access article distributed under the terms of the Creative Commons Attribution License (http://creativecommons.org/licenses/by/2.0), which permits unrestricted use, distribution, and reproduction in any medium, provided the original work is properly cited. 